\title{
WRIST HAND ORTHOSES IN THE MANAGEMENT OF UPPER LIMB SPASTICITY IN HEMIPLEGIA- A RANDOMISED CONTROLLED TRIAL STUDY
}

\author{
Naorem Bimol', Yumnam Ningthemba Singh², Taha Peya ${ }^{3}$, Yumnam Nandabir Singh ${ }^{4}$, Akoijam Joy Singh ${ }^{5}$, Shantibala Konjengbam ${ }^{6}$ \\ ${ }_{1}^{1}$ Assistant Professor, Department of Physical Medicine and Rehabilitation, Regional Institute of Medical Sciences, Imphal. \\ ${ }^{2}$ Senior Registrar, Department of Physical Medicine and Rehabilitation, Regional Institute of Medical Sciences, Imphal. \\ ${ }^{3}$ Ex-Postgraduate Trainee, Department of Physical Medicine and Rehabilitation, Regional Institute of Medical Sciences, Imphal. \\ 4 Professor, Department of Physical Medicine and Rehabilitation, Regional Institute of Medical Sciences, Imphal. \\ 5Professor, Department of Physical Medicine and Rehabilitation, Regional Institute of Medical Sciences, Imphal. \\ ${ }^{6}$ Professor, Community Medicine Department, Regional Institute of Medical Sciences, Imphal.
}

\begin{abstract}
BACKGROUND

The most significant impact on a stroke survivor is longterm disability. Patients with hemiplegia often develop abnormal patterns in the paretic limbs, primarily affecting the flexors and pronators of upper limb. Spasticity is the most common identified problem and is difficult to treat. There are very few documents on the role of wrist hand orthoses (hand splints) in the management of spasticity.

The objective of this study was to determine the effectiveness of wrist hand orthoses in the reduction of spasticity of upper limb in post stroke hemiplegia.
\end{abstract}

\section{MATERIALS AND METHODS}

All hemiplegic patients aged 35 to 75 years, who attended PMR OPD during August 2013 to July 2015 were included in the study. Only those cases with history of stroke less than six weeks duration, unable to extend the wrist actively and spasticity of $\leq$ grade 2 were included in the study. Block randomisation was used to randomise the patients into intervention and control groups. A reduction in spasticity was the main outcome measure and it was measured by Modified Ashworth Scale (MAS).

Study Design and Setting- A Randomised Controlled Trial was conducted in the Department of Physical Medicine and Rehabilitation (PMR), Regional Institute of Medical Sciences, Imphal, Manipur.

\section{RESULTS}

A total of 88 patients were enrolled for the study. 44 were assigned to intervention and 44 to control group. At the end of first followup, flexor spasticity score of $\geq 2$ was seen more among controls 28 (66.7\%) as compared to intervention group 10 (25.0\%). Biceps spasticity score of $\geq 2$ was also observed to be significantly more among controls $36(85.7 \%)$ as compared to the intervention group 10 (25.0\%). Similar finding was also observed at second followup. Effectiveness of splints in reduction of spasticity was significantly more when the duration of hemiplegia was less than two weeks.

\section{CONCLUSION}

There was significant reduction in upper limb spasticity when wrist hand orthoses (hand splint) were applied to the affected limb within two weeks of post stroke hemiplegia.

\section{KEYWORDS}

Spasticity, Wrist Hand Orthoses, Modified Ashworth Scale.

HOW TO CITE THIS ARTICLE: Bimol N, Singh YN, Peya T, et al. Wrist hand orthoses in the management of upper limb spasticity in hemiplegia- A randomised controlled trial study. J. Evolution Med. Dent. Sci. 2017;6(94):6877-6880, DOI: $10.14260 /$ jemds/2017/1490

\section{BACKGROUND}

Stroke results in significant morbidity, mortality and disability particularly among the older people. It has been shown that even though mortality from stroke has declined in the USA, hospitalisation for stroke increased. As our population ages, the incidence and prevalence of stroke will continue to rise and stroke rehabilitation will have an important role in reducing the burden of longterm stroke

'Financial or Other Competing Interest': None.

Submission 30-10-2017, Peer Review 24-11-2017,

Acceptance 01-12-2017, Published 18-12-2017.

Corresponding Author:

Dr. Shantibala Konjengbam,

Professor

Department of Community Medicine,

Regional Institute of Medical Sciences, Imphal.

E-mail:shantibaladr@yahoo.com

DOI: $10.14260 /$ jemds $/ 2017 / 1490$ care in the society. ${ }^{1}$ The most significant physical impact on stroke survivors is longterm disability. Patients with hemiplegia also often develop abnormal patterns of muscle activity in the paretic limbs in the weeks after stroke with overactivity of muscles primarily affecting flexors and pronator of the upper limb. ${ }^{2}$

The prevalence of spasticity in a post stroke hemiplegic is reported as high as $39 \% .^{3}$ Spasticity is the most common identified problem and it is a difficult motor problem to treat following stroke. Spasticity developed in few weeks after an acute stroke and if not treated correctly spasticity can progress until independent living is nearly impossible. ${ }^{4}$

Wrist hand orthoses (Hand splints) have been recommended since 1911 to prevent and treat spasticity and contracture. Splints are thought to prevent or reduce contractures and spasticity and the belief is that this will contribute to hand function, should motor recovery occur. ${ }^{4}$ Hand splints are applied in the functional position and 
generally night time is the optimal time for the patients to wear a static splint. It is also the time when the patient needs resting splints to prevent them from sleeping in a position that damages the hand. 5

There are two theories which underpin hand splinting. The first one is the biomechanical approach which emphasised the prevention or correction of deformity by mechanical application of splints. The second one is neurophysiological approach, but the exact effects of splinting on spasticity are undefined. ${ }^{6}$

Many investigators have studied the effectiveness of hand splinting in the management of spasticity and contractures with conflicting results. In India, so far, no studies have been done on hand splinting for the reduction of spasticity. So, this study was conducted to determine the effectiveness of wrist hand orthoses (hand splint) in reduction of upper limb spasticity in the post stroke hemiplegia.

\section{MATERIALS AND METHODS}

A randomised controlled trial was conducted in the Department of Physical Medicine and Rehabilitation, Regional Institute of Medical Sciences, Imphal during August 2013 to July 2015. All hemiplegic patients aged between 35 to 75 years attending the department during this period were included in the study. Only those cases with history of stroke for less than 6 weeks, unable to actively extend the wrist and spasticity of $\leq$ grade 2 were included in the study. Cases with language, comprehension or cognitive deficits that would prevent from giving informed consent, recurrent stroke, history of taking antispastic drugs and those who refused to give consent were excluded from the study. A proforma was used to collect sociodemographic and background characteristics, and spasticity scores of the study participants.

The cases were randomised into two groups by using block randomisation. A block of four was used for the study. Reduction in spasticity was the outcome measure and it was assessed by Modified Ashworth Scale (MAS). ${ }^{7}$

To both the treatment and control cases, neurodevelopmental exercises three times a day and positioning of upper limb in reflex inhibitory position was done. Cases in the intervention group were made to wear a wrist hand orthosis (Figure 1) which positions the wrist at $>45^{\circ}$ dorsiflexion, with metacarpophalangeal and interphalangeal joints in extension and thumb in extension and abduction. The participants in the intervention group were made to wear the splint for at least 12 hours a day, 8 hours at night and 4 hours during the day for 12 weeks. The cases were followed up at the end of three and six months after the initiation of study to assess the level of spasticity.

Statistical analysis was done using descriptive statistics like mean, standard deviation and percentages. For analytical statistics, chi-square test and student t-test were employed to test for significance in the difference in spasticity between the groups. A $p$ value of $<0.05$ was taken as statistically significant. Ethical approval was obtained from the Institutional Ethics Committee, Regional Institute of Medical Sciences, Imphal.

\section{RESULTS}

During the study period, 88 cases were recruited of which 44 randomised to the intervention group and 44 to the control group. All the patients who were recruited could not be followed up till the end of the study. At the end of first followup, 6 (6.8\%) patients and at the end of second followup $24(27.3 \%)$ patients were lost to followup.

\begin{tabular}{|c|c|c|c|}
\hline Characteristics & $\begin{array}{c}\text { Intervention } \\
\mathrm{N}(\%)\end{array}$ & $\begin{array}{c}\text { Control } \\
\mathrm{N}(\%)\end{array}$ & $P$ - value \\
\hline \begin{tabular}{|c|} 
Mean Age, years \\
(SD)
\end{tabular} & $60.8(12.0)$ & $58.6(13.7)$ & 0.412 \\
\hline $\begin{array}{c}\text { Gender } \\
\text { No. of women } \\
(\%) \\
\end{array}$ & $18(48.6)$ & $19(51.4)$ & 0.829 \\
\hline $\begin{array}{l}\text { Religion } \\
\text { Hindu } \\
\text { Christian } \\
\text { Muslim } \\
\end{array}$ & $\begin{array}{l}37(51.4) \\
4(40.0) \\
3(50.0)\end{array}$ & $\begin{array}{c}35(48.6) \\
6(60.0) \\
3(50.0)\end{array}$ & 0.796 \\
\hline $\begin{array}{c}\text { Side of } \\
\text { hemiplegia } \\
\text { Right } \\
\text { Left }\end{array}$ & $\begin{array}{l}24(50.0) \\
20(50.0)\end{array}$ & $\begin{array}{l}24(50.0) \\
20(50.0)\end{array}$ & 0.585 \\
\hline \begin{tabular}{|c}
$\begin{array}{c}\text { Duration } \\
<1 \text { week }\end{array}$ \\
$1-2$ weeks \\
$2-3$ weeks \\
$>3$ weeks but< 6 \\
weeks \\
\end{tabular} & $\begin{array}{l}22(56.4) \\
12(50.0) \\
3(50.0) \\
7(36.8)\end{array}$ & $\begin{array}{c}17(43.6) \\
12(50.0) \\
3(50.0) \\
12(63.2)\end{array}$ & 0.581 \\
\hline $\begin{array}{c}\text { Finger Flexor } \\
\text { Spasticity Score } \\
0 \\
1\end{array}$ & $\begin{array}{l}20(45.5) \\
24(54.5)\end{array}$ & $\begin{array}{l}16(36.4) \\
28(63.6)\end{array}$ & 0.386 \\
\hline $\begin{array}{c}\text { Biceps } \\
\text { Spasticity Score } \\
0 \\
1 \\
2\end{array}$ & $\begin{array}{l}28(63.6) \\
9(20.5) \\
7(15.9)\end{array}$ & $\begin{array}{l}15(34.1) \\
18(40.9) \\
11(25.0)\end{array}$ & $0.020^{*}$ \\
\hline
\end{tabular}

$* \mathrm{P}<0.05$

Table 1 showed the background characteristics of the study participants. There were no significant differences in the baseline characteristics like age, sex, religion and side of hemiplegia between the study groups. However, it was observed that the proportion of patients in the control group with duration of hemiplegia more than three weeks at the initiation of study was more than the intervention group. The difference was, however, observed to be statistically not significant. Flexor spasticity scores are not significantly different among the cases and controls. Regarding biceps spasticity, proportion with higher scores were more in controls $11(61.1 \%)$ as compared to intervention group 7 (38.9\%) and the difference was found to be statistically significant.

\begin{tabular}{|c|c|c|c|}
\hline \multirow{2}{*}{$\begin{array}{c}\text { Spasticity } \\
\text { Score (MAS) }\end{array}$} & \multicolumn{2}{|c|}{$1^{\text {st }}$ Followup } & \multirow[b]{2}{*}{$P$ - value } \\
\hline & $\begin{array}{l}\text { Intervention } \\
\text { Group N (\%) }\end{array}$ & $\begin{array}{c}\text { Control Group } \\
\mathrm{N}(\%)\end{array}$ & \\
\hline $\begin{array}{c}\text { Flexors } \\
\text { spasticity }\end{array}$ & & & \\
\hline 0 & $3(7.5)$ & $0(0.0)$ & \\
\hline 1 & $27(67.5)$ & $14(33.3)$ & $0.001^{*}$ \\
\hline 2 & $10(25.0)$ & $26(61.9)$ & \\
\hline 3 & $0(0.0)$ & $2(4.8)$ & \\
\hline
\end{tabular}




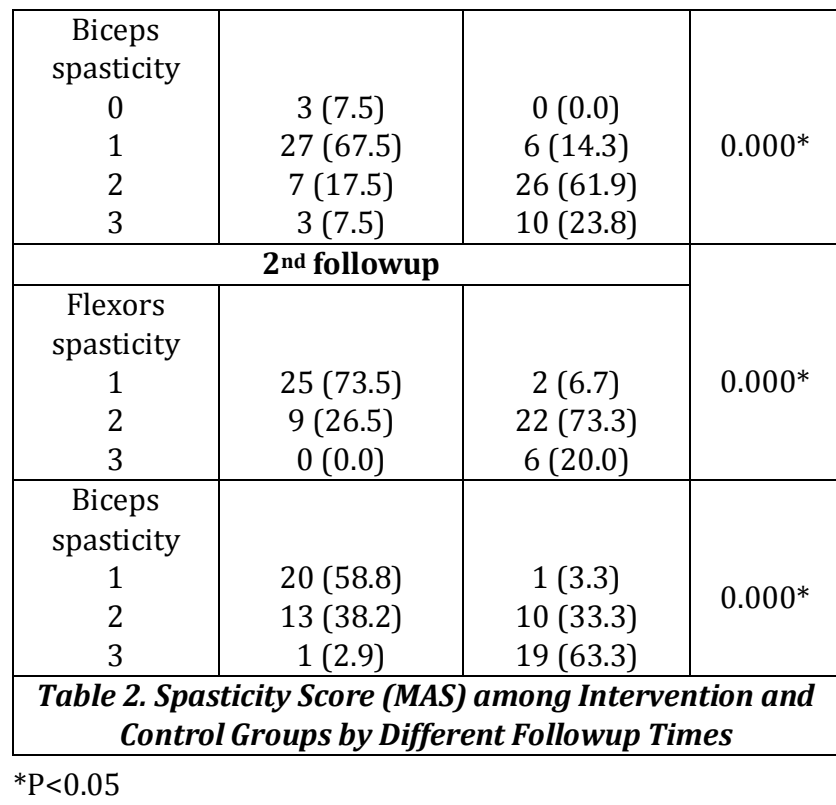

Table 2 shows that at first followup, finger flexor spasticity score of $\geq 2$ were observed in $28(66.7 \%)$ cases in the control group as compared to only $10(25 \%)$ cases in the intervention group and the difference was observed to be statistically significant. The proportion of cases with biceps spasticity scores of $\geq 2$ were observed to be significantly more among control group $36(85.7 \%)$ as compared to intervention group 10 (25.0\%). At second followup, cases with finger flexor spasticity scores of $\geq 2$ were observed to be significantly more in the control group 28 (93.3\%) as compared to only $9(26.5 \%)$ in the intervention group.

For biceps spasticity, at second followup, 29 (96.6\%) cases in the control group had MAS score $\geq 2$ as compared to only 14 $(41.1 \%)$ in the intervention group.

\begin{tabular}{|c|c|c|c|c|c|c|c|}
\hline \multirow{2}{*}{\multicolumn{2}{|c|}{ Duration of Hemiplegia }} & \multicolumn{2}{|c|}{$\begin{array}{c}\text { Flexor Spasticity Score } \\
\text { at } 1^{\text {st }} \text { Followup }\end{array}$} & \multirow[t]{2}{*}{$P$ - value } & \multicolumn{2}{|c|}{$\begin{array}{c}\text { Flexor Spasticity Score at } \\
2^{\text {nd }} \text { Followup }\end{array}$} & \multirow[t]{2}{*}{ P-value } \\
\hline & & $\leq 1$ & $\geq 2$ & & $\leq 1$ & $\geq 2$ & \\
\hline \multirow{2}{*}{$<1$ week } & Treatment N (\%) & $20(90.9)$ & $2(9.1)$ & \multirow{2}{*}{$0.024^{*}$} & $12(63.2)$ & $7(36.8)$ & \multirow[b]{2}{*}{$0.003^{*}$} \\
\hline & Control N (\%) & $9(56.2)$ & $7(43.8)$ & & $1(7.7)$ & $12(92.3)$ & \\
\hline \multirow{2}{*}{$1-2$ weeks } & Treatment N (\%) & $8(72.7)$ & $3(27.3)$ & \multirow{2}{*}{0.100} & $2(20.0)$ & $8(80.0)$ & \multirow[b]{2}{*}{0.477} \\
\hline & Control N (\%) & $4(33.3)$ & $8(66.7)$ & & $0(0.0)$ & $8(100.0)$ & \\
\hline \multirow{2}{*}{$2-3$ weeks } & Treatment N (\%) & $1(100.0)$ & $0(0.0)$ & \multirow{2}{*}{1.000} & $1(100.0)$ & $0(0.0)$ & \multirow[b]{2}{*}{0.333} \\
\hline & Control N (\%) & $1(33.3)$ & $2(66.7)$ & & $0(0.0)$ & $2(100.0)$ & \\
\hline \multirow[b]{2}{*}{$>3$ weeks } & Treatment N (\%) & $1(16.7)$ & $5(83.3)$ & \multirow[b]{2}{*}{0.232} & $0(00.0)$ & $4(100.0)$ & \multirow[b]{2}{*}{0.236} \\
\hline & Control N (\%) & $0(0.0)$ & $11(100.0)$ & & $0(0.0)$ & $7(100.0)$ & \\
\hline Total & & $44(53.7)$ & $38(46.3)$ & & $16(25)$ & $48(75.0)$ & \\
\hline
\end{tabular}

Table 3 showed that at first followup, 20 (90.9\%) cases in the intervention group and only 9 (56.2\%) in the control group had spasticity scores $\leq 1$ when the duration of hemiplegia was less than 1 week and the finding was statistically significant $(\mathrm{P}=0.024)$. The proportion of study participants who scored $\geq 2$ increased as the duration of hemiplegia increased to $\geq 1$ week and even though the proportion of control group who had higher scores was observed to be more than the intervention group, the finding was not statistically significant.

At second followup, majority $(12,63.2 \%)$ of cases in the intervention group and only $1(7.7 \%)$ in the control group had lower scores $(\leq 1)$ when the duration of hemiplegia was $<1$ week and the finding was found to be statistically significant $(\mathrm{P}=0.003)$. However, when the duration of hemiplegia was more than 1 week, even though the proportion of participants in the intervention who had higher scores was less than that in the control group, the differences were not statistically significant.

\begin{tabular}{|c|c|c|c|c|c|c|c|}
\hline \multicolumn{2}{|c|}{ Duration of Hemiplegia } & \multicolumn{2}{|c|}{$\begin{array}{c}\text { Biceps Spasticity Score } \\
\text { at 1st Followup }\end{array}$} & \multirow[t]{2}{*}{$P$ - value } & \multicolumn{2}{|c|}{$\begin{array}{c}\text { Biceps Spasticity Score } \\
\text { at 2nd Followup }\end{array}$} & \multirow[t]{2}{*}{ P-value } \\
\hline & & $\leq 1$ & $\geq 2$ & & $\leq 1$ & $\geq 2$ & \\
\hline \multirow{2}{*}{$<1$ week } & Treatment N (\%) & $19(86.4)$ & $3(13.6)$ & \multirow{2}{*}{$0.002^{*}$} & $12(63.2)$ & $7(36.8)$ & \multirow[b]{2}{*}{$0.000 *$} \\
\hline & Control N (\%) & $4(25.5)$ & $12(74.9)$ & & $1(7.7)$ & $12(92.3)$ & \\
\hline \multirow{2}{*}{$\begin{array}{c}1-2 \\
\text { weeks }\end{array}$} & Treatment N (\%) & $8(72.7)$ & $3(27.3)$ & \multirow{2}{*}{$0.005^{*}$} & $7(70.0)$ & $3(30.0)$ & \multirow[b]{2}{*}{$0.001^{*}$} \\
\hline & Control N (\%) & $1(8.3)$ & $11(91.7)$ & & $0(0.0)$ & $8(100.0)$ & \\
\hline \multirow{2}{*}{$\begin{array}{c}2-3 \\
\text { weeks }\end{array}$} & Treatment N (\%) & $1(100.0)$ & $0(0.0)$ & \multirow{2}{*}{1.000} & $1(100.0)$ & $0(0.0)$ & \multirow[b]{2}{*}{0.223} \\
\hline & Control N (\%) & $1(33.3)$ & $2(66.7)$ & & $0(0.0)$ & $2(100.0)$ & \\
\hline \multirow{2}{*}{$>3$ weeks } & Treatment N (\%) & $2(33.3)$ & $4(66.7)$ & \multirow{2}{*}{0.065} & $0(0.0)$ & $4(100.0)$ & \multirow[b]{2}{*}{0.242} \\
\hline & Control N (\%) & $0(0.0)$ & $11(100.0)$ & & $0(0.0)$ & $7(100.0)$ & \\
\hline Total & & $36(43.9)$ & $46(56.1)$ & & $21(32.8)$ & $43(67.2)$ & \\
\hline
\end{tabular}

$* \mathrm{P}<0.05$ 


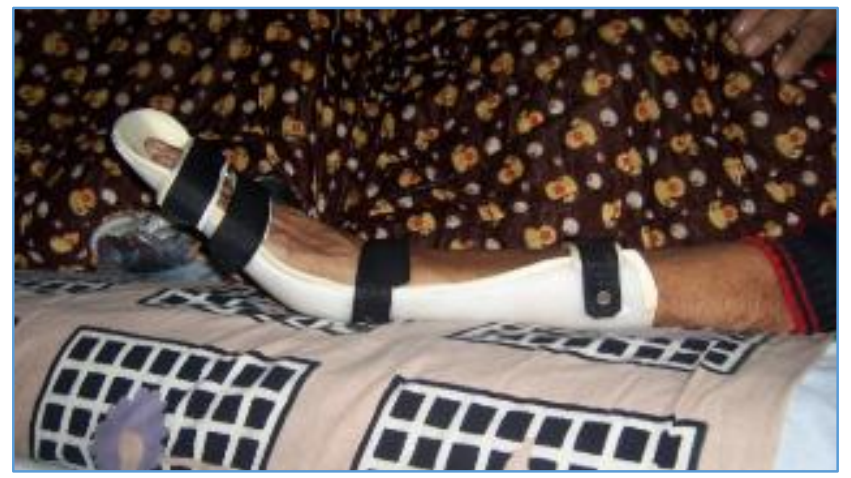

Figure 1: Patient Wearing the Wrist Hand Orthosis

Table 4 showed that at first followup, majority of the participants in the intervention group 19 (86.4\%) and only 1 $(7.7 \%)$ in the control group had lower flexor spasticity score $(\leq 1)$ when the duration of hemiplegia was $<1$ week and the finding was statistically significant $(\mathrm{P}=0.002)$. When the duration was 1-2 weeks, still majority of the participants 8 $(72.7 \%)$ in the intervention group had score $\leq 1$ as compared to only $1(8.3 \%)$ in the control group and the finding was statistically significant $(\mathrm{P}=0.005)$. However, when the duration of hemiplegia was $\geq 2$ weeks, the proportion of participants in the intervention group with lower scores was more than the control group, the findings were not statistically significant. At second followup, when the duration of hemiplegia was $<1$ week, the majority of participants 12 (63.2) in the intervention group and only 1 $(7.7 \%)$ in the control group had score $\leq 1$ and the difference was found to be statistically significant $(\mathrm{P}=0.003)$. When the duration was 1-2 weeks, majority of participants in the intervention group $7(70.0 \%)$ had score $\leq 1$ as compared to those in the control group and the difference was found to be statistically significant $(\mathrm{P}=0.001)$. When the duration of hemiplegia increased to $\geq 2$ weeks, the control group was observed to have higher scores, the finding was not statistically significant.

\section{DISCUSSION}

Spasticity reduced significantly in the intervention group when splinting was done in the first 1-2 weeks of onset of hemiplegia. At first and second followup of the cases, there was significant difference in the spasticity scores between intervention and control groups. The proportions of cases with high spasticity scores as measured by Modified Ashworth Scale was higher in the control group as compared to the intervention group in both first and second followup. At first followup, 28 (61\%) patients in the control group had finger flexor spasticity score of grade 2 as compared to only $10(25 \%)$ in the intervention group and this finding was found to be statistically significant. Biceps spasticity score of 2 was observed in $26(61.9 \%)$ patients of the control group as compared to only $7(17.5 \%)$ in the intervention group and it was statistically significant. A similar finding was also observed at second followup. At third followup, since only 10 cases were available, analysis was not done. Similar findings of this reduction in spasticity after splinting were also observed by other investigators. $2,8,9,10,11$ However, some other studies have also reported that splinting has no clinically beneficial effects in contrast to study findings. ${ }^{12,13,14}$

Reduction in spasticity by splinting was observed to be more effective when the duration of hemiplegia was less than two weeks. Similar findings were also observed in one study indicating that delaying onset of intervention may be counterproductive. ${ }^{6}$ Early intervention is important as muscle contractures are likely to develop both immediately and through several weeks, months post stroke. However, it has to be noted that at the onset of study, the control group had significantly higher biceps spasticity scores as compared to the intervention group. Therefore, while interpreting the results of this study the above findings need to be kept in mind.

\section{CONCLUSION}

Therefore, it can be concluded from the present study that there is significant reduction in spasticity if the wrist hand orthosis is applied to the affected limb as early as possible preferably within two weeks of post stroke hemiplegia.

\section{REFERENCES}

[1] Harvey LR, Roth JE, Yu D. Rehabilitation of stroke syndromes. In: Bradom LR, eds. Physical medicine and rehabilitation. $3^{\text {rd }}$ edn. New York: WB Saunders 2007:1175-212.

[2] Gracies JM, Marosszeky JE, Renton R, et al. Short-term effects of dynamic Lycra splints on upper limb in hemiplegic patients. Arch Phys Med Rehabil 2000;81(12):1547-55.

[3] Ozcakir S, Sivrioglu K. Botulinum toxin in poststroke spasticity. Clin Med Res 2007;5(2):132-8.

[4] Chapter-1 http://Libraryuws.edu.au/adtNUWS/uploads/approved/adt-NUWS 20061016095639/public/02chapter1pdf. 15.09.2013.

[5] Belkin J, English CB, Adler C, et al. Hand splinting: principles, practice and decision making. In: Pedritti LW, ed. Occupational therapy, practice skills for physical dysfunction. $4^{\text {th }}$ edn. St. Louis: Mosby 1996:319-43.

[6] Wilton JC. Splinting and casting in the presence of neurological dysfunction. In: Wilton JC, ed. Hand splinting: principles of design and fabrication. London: WB Saunders 1997:168-97.

[7] Bohannon RW, Smith MB. Interrater reliability of a modified Ashworth scale of muscle spasticity. Phys Ther 1987;67(2):206-7.

[8] McPherson JJ, Kreimeyer D, Aalderks M, et al. A comparison of dorsal and volar resting hand splints in the reduction of hypertonus. Am J Occup Ther 1982;36(10):664-70.

[9] Scherling E, Johnson H. A tone-reducing wrist-hand orthosis. Am J Occup Ther 1989;43(9):609-11.

[10] Brennan JB. Response to stretch of hypertonic muscle groups in hemiplegia. BMJ 1959;1(5136):1504-7.

[11] Kaplan N. Effects of splinting on reflex inhibition and sensorimotor stimulation in treatment of spasticity. Arch Phys Med Rehabil 1962;43:565-9.

[12] Lannin NA, Horsley SA, Herbert R, et al. Splinting the hand in functional position after brain impairment: a randomized controlled trial. Arch Phys Med Rehabil 2003;84(2):297-302.

[13] Barnes MP. Management of spasticity. Age Ageing 1998;27(2):239-45.

[14] Park EH, Kang JY, Chun MH. Effects of resting hand splints in early stroke patients. J Korean Acad Rehabil Med 2006;30(3):261-65. 